特集 大型-巨大脳動脈瘤の外科治療

\title{
後頭蓋窩血栓性巨大脳動脈瘤の外科治療
}

\author{
氏家弘 ${ }^{1}$, 上山 博康 ${ }^{2}$, 比嘉 隆 $^{1}$

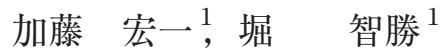

\section{Surgical Treatment of Thrombosed Giant Aneurysms in the Posterior Fossa}

\author{
Hiroshi UJIIE, M.D., ${ }^{1}$ Hiroyasu Kamiyama, M.D., ${ }^{2}$ Takashi Higa, M.D., ${ }^{1}$ \\ Koichi Kato, M.D., ${ }^{1}$ and Tomokatsu HoRI, M.D. ${ }^{1}$ \\ ${ }^{1}$ Department of Neurosurgery, Tokyo Women's Medical University, Tokyo, and ${ }^{2}$ Department of \\ Neurosurgery, Asahikawa Red Cross Hospital, Asahikawa, Japan
}

Summary: Giant fusiform aneurysms are characterized by tortuosity, elongation, distention, and partial thrombosis, and are most frequently found in the vertebrobasilar circulation. Surgical removal of these aneurysms is the treatment of choice for such lesions because they often develop mass signs. We report 14 surgically treated cases that were classified into so-called thrombosed aneurysms in the posterior fossa (VA involved: 9, VA-BA involved: 3, BA involved: 2). Four cases out of 9 VAinvolved cases were treated with aneurysmal trapping and aneurysmectomy after OA-PICA anastomosis. The other 5 cases were trapped and aneurysmectomy was performed because of no involvement of PICA flow. Seven out of 9 cases showed very excellent surgical outcomes instead of preoperative pyramidal signs. However, 5 cases involving VA-BA or BA were treated with high flow bypass (VA-RA-PCA bypass), and Hunterian ligation showed very poor surgical outcomes. Only 1 case recovered well after surgery and resumed social activity. The unsatisfactory results were considered to be caused by high flow bypass flew up thrombus induced within the blind aneurysm sac into the perforators, resulting in catastrophic central pontine infarction. The enhanced reversed flow through the bypass caused the already thrombosed aneurysms to grow. We analyze the operative results and discuss the pathogenesis.

\section{Key words:}

- thrombotic aneurysm

- dolichoectatic aneurysm

- radial artery bypass

- high flow bypass

- giant aneurysm

Surg Cereb Stroke

(Jpn) 37: 149-155, 2009

\section{はじめに}

一般に後頭蓋窩巨大動脈瘤の予後はきわめて悪く, 放置 した場合 $2-3$ 年以内に $50 \%$ 以上の死亡率が報告されてい る 1) 16) 27). 後頭蓋窩の血栓化動脈瘤が mass effect で発症 した場合, 動脈瘤は成長し脳幹部を圧迫し, 血栓腔の伸展 による脳梗塞の発症，さらにはSAHの発症などをきたす
ため，なんらかの外科的処置が必要になることが多い。椎 骨動脈は左右 2 本存在するので, 動脈瘤の発生した一側の 椎骨動脈を犠牲にできることが多く，比較的容易に外科的 治療方針を立てることができ，その手術予後も良好である。 しかし脳底動脈に血栓性動脈瘤病変が生じた場合, 脳底動 脈を犠牲にすることはできず，治療はきわめて困難であ る ${ }^{1-5) 12) 15) 25-27)}$.もちろん可能であれば, 脳幹部を圧迫

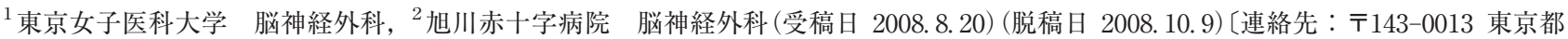
大田区南大森4-13-21 東京労災病院 脳神経外科 氏家 弘] [Address correspondence: Hiroshi UJIIE, M.D., Department of Neurosurgery, Tokyo Women's Medical University, 8-1 Kawada-cho, Shinjuku-ku, Tokyo 143-0013, Japan]
} 
Table 1 Summary of patients

\begin{tabular}{|c|c|c|c|c|c|c|}
\hline No & Age & Sex & Location & Symptom & Surgery & O utcome \\
\hline 1 & 48 & M & $\mathrm{BA}$ & M ass, hydro & bil VA ligation, VA-RA-PCA, O A-PIC A, STA-SCA a nastomosis & dead due to pneumonia \\
\hline 2 & 47 & M & $\mathrm{BA}$ & M ass & BA proximal clip, VA-RA-PCA, STA-SCA a nastomosis & good recovery \\
\hline 3 & 45 & $\mathrm{~F}$ & it VA-BA & M ass, TIA & bil VA ligation, VA-RA-PCA, OA-AICA, STA-SCA a nastomosis & dead due to pulmonary embolism \\
\hline 4 & 43 & M & It VA-BA & M ass & It VA clipping, VA-RA-PCA, STA-SCA a nastomosis, it VA coiling & vegetative state \\
\hline 5 & 55 & M & It VA-BA & M ass & It VA clipping, VA-RA-PCA, STA-SCA a nastomosis & severely disabled \\
\hline 6 & 48 & M & it VA & $\mathrm{SAH}$ & It VA trapping, a neurysmectomy & good recovery \\
\hline 7 & 38 & M & rt VA & M ass & it VA trapping, a neurysmectomy & dead \\
\hline 8 & 64 & M & it VA & M ass & it VA proximal clip, O A-PICA anastomosis & good recovery \\
\hline 9 & 57 & M & It VA & SAH, M ass & It VA trapping, a neurysmectomy, O A-PIC A a nastomosis & good recovery \\
\hline 10 & 68 & M & it VA & M ass & it VA trapping, aneurysmectomy, O A-PIC A a nastomosis & good recovery \\
\hline 11 & 59 & M & it VA & M ass & it VA trapping, a neurysmectomy & good recovery \\
\hline 12 & 48 & M & rt VA & Mass & it VA trapping, a neurysmectomy & good recovery \\
\hline 13 & 52 & M & it VA & M ass & it VA trapping, a neurysmectomy & good recovery \\
\hline 14 & 43 & M & It VA & M ass & It VA trapping, a neurysmectomy, O A-PIC A & good recovery \\
\hline
\end{tabular}

している血栓化動脈瘤自体の摘出を行い, 脳底動脈を温存 することが最も理想的な治療であるが，これには多くの問 題が残されている. 脳底動脈先端の後大脳動脈, 上小脳動 脈には血行再建術が可能であるが, 脳底動脈から直接分岐 する小さな穿通枝動脈には血行再建術は不可能なので, 脳 底動脈を trapする場合短時間でも穿通枝動脈閉塞による 脳幹梗塞を生じる可能性がある.われわれは脳底動脈およ び穿通枝動脈の血流を維持しながら, 動脈瘤の成長を止め るために血流の方向を変え, かつ動脈瘤全体を盲端として 血栓化させる方針を治療として選択した。しかしその術後 経過は予想とは違い, 社会復帰が可能となったものは 5 例 中1例のみであった。

この論文では椎骨動脈および脳底動脈病変の発生メカニ ズムに文献的考察を行い, そしてその手術方法と合併症に ついて検討，報告する.

\section{対象および方法}

1996 年 8 月から 2006 年 5 月までの約 10 年間に東京女子 医大病院で直達手術を行った後頭蓋窩血栓性動脈瓷は 14 例であった。症例の男女比は $13 ： 1$ で男性に優位に発症 し, 年齢分布は 38-68歳, 平均発症年齢は 48.8歳であった. 病変部位は, 椎骨動脈 $(\mathrm{VA})$ が 9 例, 脳底動脈 $(\mathrm{BA})$ が 2 例, 椎骨脳底動脈 (VA-BA)が 3 例であった。動脈瘤は非分岐 部動脈瘤 13 例, 1 例で脳底動脈空形成部に生じた囊上動 脈瘤であり, largeに分類された動脈瘤はVAの 3 例のみ で, 他のVA 6例, VA-BA 3例, BA 2例はすべて giant に分類され, 全症例で動脈瘤内に血栓を伴っていた. 初発 症状は mass effectによる神経脱落症状が 12 例で，この 12 例中 1 例では脳幹部梗塞を繰り返していた。 くも膜下出血
(SAH) で発症した症例は 2 例であった. SAHのうち 1 例 は他院で保存的に治療を受けた 3 年後に mass effectによ る右不全麻疩で再発した. mass effect発症例のうち 1 例 は, 閉塞性水頭症を伴っていた。全例で血行再建術を含め た外科的治療を行った。手術結果は術後 6 力月後に Glasgow Outcome Scaleに従って GR (good recovery), MD (moderately disability), SD (severe disability), VS (persistent vegetative state), D (death)の5段階に分類 し判定した.

\section{結果}

14 症例の治療結果を Table 1 に示す.

椎骨動脈瘤 9 例中 4 例で OA-PICA 吻合術を行った. 4 例中 1 例で後頭動脈-後下小脳動脈 (OA-PICA) 吻合術後お よびVA近位部の clippingを行い，3例では OA-PICA吻 合術後に動脈瘤の前後で trapping そして aneurysmectomy を行った. OA-PICA 吻合術 4 例では，術後その血流は 全例でよく保たれており，術後にPICA 領域に脳虚血を発 症した症例はなかった.9例中 5 例ではすでにPICA が動 脈瘤に巻き込まれ閉塞していたので, 血行再建術は施行せ ず血栓化動脈瘤摘出のみを行った。また 1 例ではすでに VAが動脈瘤近位部で閉塞していた。術後経過は，GR 7 例，MD 1例(case 9)，D 1例(case 7)であった. Dの経 過となった症例は, 術後に嚥下困難, 睡眠時呼吸障害を併 発し，リハビリ病院へ転院後夜間に窒息によると思われる 突然死を生じた。 MDの 1 例は, 術後 3 週間目にV-P shunt (3年前に SAHを生じたときに施行された)への MRSA 感染さらに脳室炎を併発し, 社会復州不能となり MD となった. GRに分類された 7 症例の術後神経症状の 

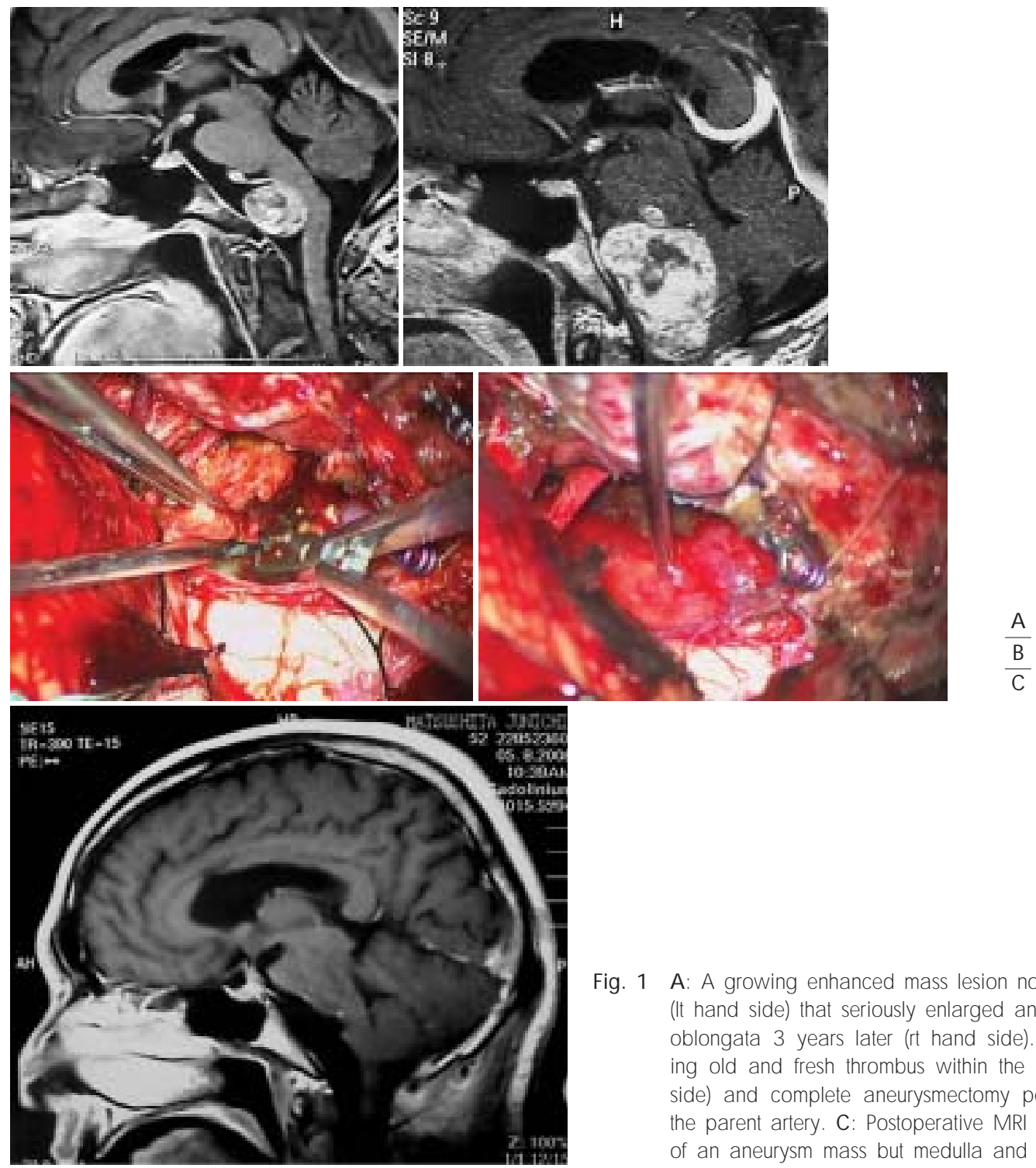

Fig. 1 A: A growing enhanced mass lesion noted in premedullary cistern (It hand side) that seriously enlarged and compressed the medulla oblongata 3 years later (rt hand side). B: 0 perative view show ing old and fresh thrombus within the aneurysm capsule (It hand side) and complete aneurysmectomy performed after trapping of the parent artery. C: Postoperative M RI showing complete removal of an aneurysm mass but medulla and pons still deformed.

変化を次のごとくである。術前, 動脈瘤が大きくなるほど VII-XII脳神経障害, 小脳症状, 錐体路症状を組み合わせ た多彩な症状が出現していた。GRに分類された 7 例中 5 例で術前に存在した錐体路症状は, 動脈瘤摘出によって全 例で著明に改善した。しかし術前に錐体路症状はなかった 1例で，延髄にはまり込んでいる血栓化動脈瘤を摘出する ことによって, 術後に片麻幹が出現しリハビリテーション を必要とした。術前に聴力障害を認めた症例では，術後に 聴力回復を認めた症例はなかった。術後に新たに顔面神経 麻痺が 1 例で出現し, 顔面神経再建術を行った. IX, X脳 神経障害は, 術直後 7 例中 6 例で悪化したが, 術後 3 力月 以内に嚥下障害は回復した。しかし軽度の嗄声は全例で残 存した.XII脳神経障害を術前に認めなかった症例でも,
動脈瘤が巨大な 4 症例では全例に術後 XII 脳神経障害を認 めた. 血栓化動脈瘤を摘出後にXII 脳神経の存在を丹念に 調べた 3 症例で，まったくXII脳神経を確認できなかった (症例 12, Fig. 1). XII脳神経は血栓化椎骨動脈瘤で, 最 も圧迫され薄片化しているものと考えられた。

脳底動脈を巻き込んだ血栓化巨大動脈瘤 5 例は, すべて repeated stroke および mass effectで発症していた.この 5 症例すべてに椎骨動脈と後大脳動脈間に橈骨動脈グラフ トを用いて血行再建術を行ったのち, 親動脈閉塞を行った が, aneurysmectomyは 1 例のみで行った. 血行再建術直 後に脳底動脈のクリップによる閉塞を 1 例, 両側椎骨動脈 のクリップによる閉塞を 2 例に行った. 1 例では血行再建 術後に一側椎骨動脈の完全閉塞と, 反対側椎骨動脈の不完 

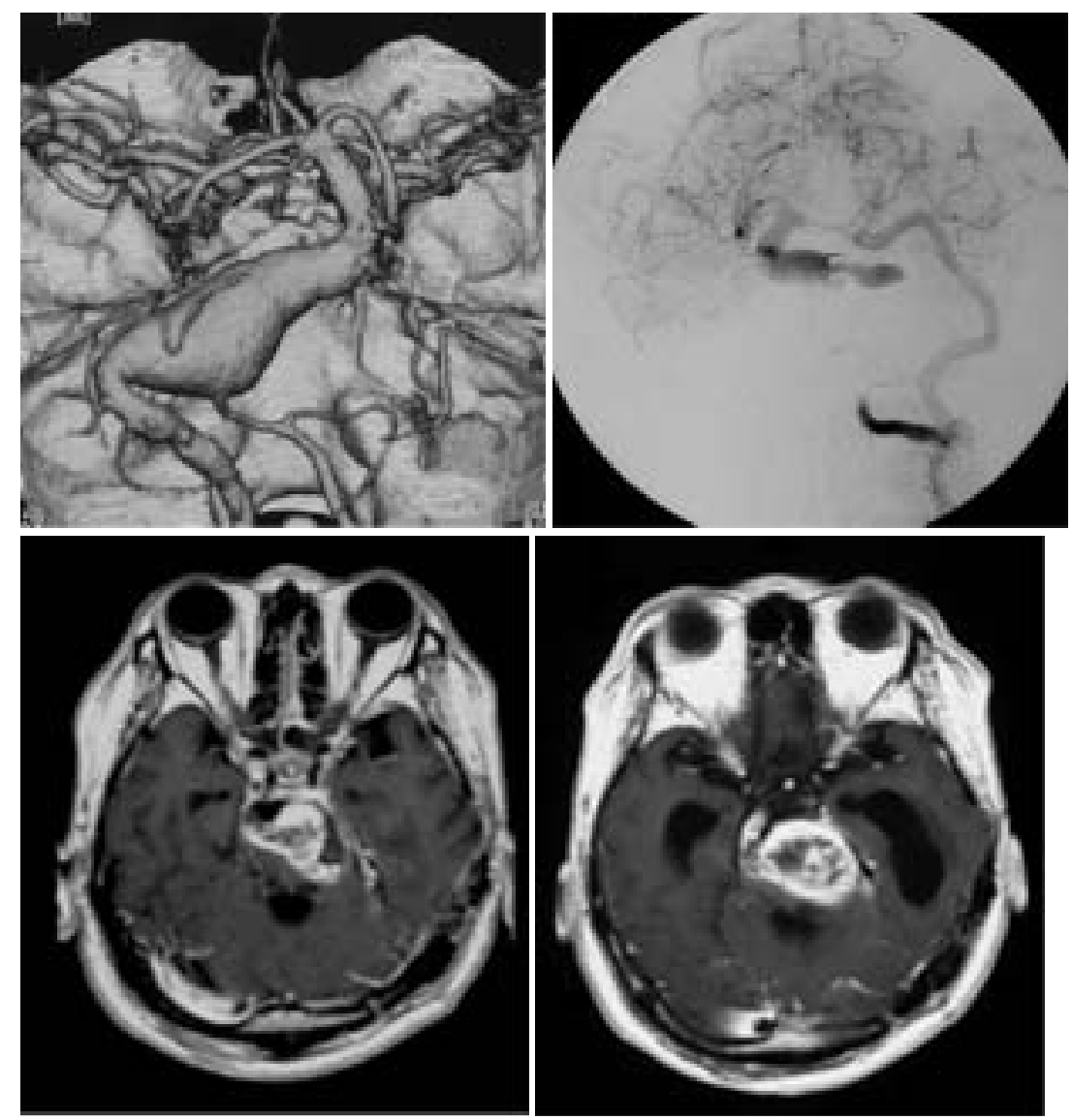

$\frac{\mathrm{A}}{\mathrm{B}}$

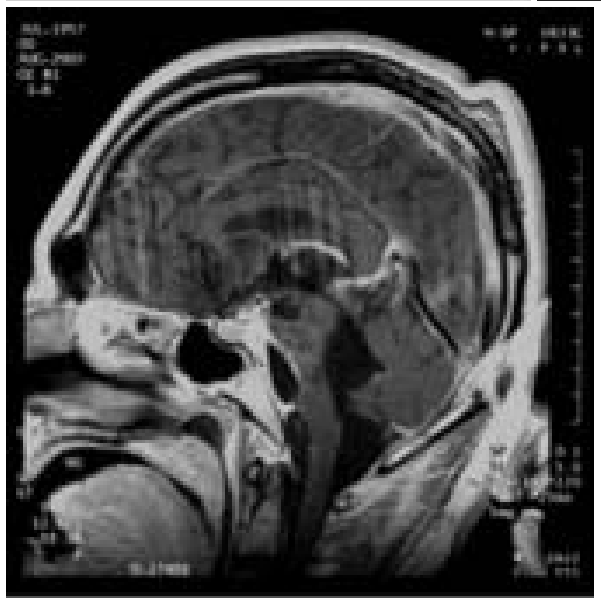

Fig. 2 A: Dolichoectatic a neurysm involving bilateral vertebral arteries (It hand side) treated with Hunterian ligation of It vertebral artery after making VA-RA-PCA bypass. 0 ne week later it vertebral artery was occluded with coiling, but 6 hours later thrombus quickly developed within the aneurysm and a part of thrombi flew into the perforators of the basilar artery (rt hand side). B: After coiling of the distal basilar artery via the RA bypass graft, the thrombosed aneurysm (It hand side) did not shrink but still keeping to grow (rt hand side). C: The growing aneurysm mass after coil trapping was completely removed together with the basilar artery.

全閉塞を同時に行ったが，術直後の血管撮影では両側の椎 骨動脈は閉塞していた。すなわち，5例中 4 例で血行再建 術と親動脈閉塞が同時に行われ，1例で血行再建術後に一 側椎骨動脈 VAの近位部閉塞を行って手術を終了したの ち，10日目に対側 VAの coil embolizationを行った(症例 4)。これらの症例では橈骨動脈 (RA)を用いた椎骨動脈一後 大脳動脈 (VA-PCA) 間の high flow bypassのほかに, 浅側 頭動脈一上小脳動脈 (STA-SCA) bypass, OA-PICA by- pass，後頭動脈-前下小脳動脈 (OA-AICA) bypass を行っ た.VA-RA-PCA bypassは, 両側後交通動脈が発達して いる 1 例を除いた 4 例で逆行性に脳底動脈近位部まで良好 に流れていた。 またSTA-SCA bypassは順向性にSCA 末 梢に急性期のみ流れていた。

これら脳底動脈を巻き达んだ巨大血栓化動脈瘤 5 例の手 術予後は, GR 1例, SD 1例, VS 1例，D 2 例であった. 血行再建術と親動脈閉塞を同時に行った 4 症例で，術直後 
にヘパリンを使用したにもかかわらず全例で脳幹部虚血症 状を併発し, 術後脳神経麻瘏, 片麻痺を発症した。この 4 症例中 2 例では神経症状は回復することなく 1 例では家庭 内復帰 (SD: 顔面神経麻痺, 聴神経障害, 下位脳神経麻痺), またもう 1 例では四肢麻痺の状態で転院したのちに肺炎で 死亡した (D). 4 例中 2 例では術後神経症状は改善したが, しかし 1例では術後 EDH を合併したためへパリンを中止 せざるを得なく, 脳幹梗塞は広範囲となり片麻痺および意 識障害を後遺し，6力月後に肺塞栓症を合併し突然死した (D: case 3). 2 例中 1 例では術後神経症は改善し, 職場復 帰を果たすことができた。この症例 (case 2) は, dolichoectatic basilar arteryを合併していなかった。また術後脳 血管撮影で脳底動脈はまったく造影されなかったが，脳幹 部には小さな梗塞のみが認められた $(\mathrm{G})$. 手術後 1 週間目 に反体側 VA をコイルで閉塞した症例 (case 4)では, 塞栓 術 6 時間後に突然動脈瘤内に生じた血栓による脳幹梗塞を 生じ四肢麻痺の経過をとった (Fig. 2A). そして術後さら に血栓化動脈瘤は増大し，BA 全体を含めた aneurysmectomyを行った (Fig. 2B，C).すなわちVA-RA-PCA bypass は，脳底動脈を逆行性に流れてもその脳底動脈穿 通枝領域を十分に還流できず盲端となった脳底動脈が血栓 化すると同時に穿通枝血管に梗塞が生じたと考えられる. またVA-RA-PCA bypassを行った 5 症例中 1 例では，そ の後著明な動脈瘤の成長，増大を認め，他の症例でも縮小 は認めなかった。

\section{考察}

\section{解離性椎骨動脈瘤発症のメカニズムに対する考察}

椎骨動脈は第 1,2 澒椎で外側へループを形成したのち, 後方から硬膜を貫通し，両側の椎骨動脈が合流して 1 本の 脳底動脈へと移行する．椎骨動脈および脳底動脈にはいく つかの解剖学的および流体力学的特徴が指摘される 27）.1）頚椎部椎骨動脈は，頚椎の運動に伴い常に引っ張 り，ねじれなどの外的応力にさらされている．2）両側の 椎骨動脈が非対称性の場合，椎骨脳底動脈は動圧差によっ て細い椎骨動脈側へ伸展変位し, 動脈硬化の生じやすい屈 曲蛇行した動脈となる。3）椎骨動脈には豊富な栄養血管 (vasa vasorum)の発達が認められる。そして脳底動脈は 長さ約 $3 \mathrm{~cm}$, 径 $3 \mathrm{~mm}$ の動脈で橋延髄溝の前方で両側の 椎骨動脈が合流して形成される，4）脳底動脈は左右の椎 骨動脈が非対称なとき，加歯とともに彎曲し，正中から離 れ，S字状の曲線を描くようになる. Stehbens は実験的 に作成したU字型に彎曲した動脈を経時的に調べ，その 彎曲部に一致して血流の最も早いところで，壁が薄くな り，組織学には同部に内弾性板の亀裂，中膜の変性を認め たと報告している ${ }^{24)}$ 。また Roach は，実験的に狭窄後拡
張部に生じる乱流，渦流れが動脈壁に振動を引き起こし， 内弾性板の磨耗の原因となり，動脈瘤壁に広範囲にわたっ て内弾性板の欠落を最終的に引き起こしたと報告してい $る^{22)}$. 椎骨動脈および脳底動脈には解離性病変が内頚動 脈系に比較して解剖学的に起きやすいと考えられる。おそ らく動脈壁の解離を発端として壁内血栓が生じ，そして血 栓内への新生血管，器質化した血栓内への出血，また血栓 の融解による血流再開，血栓に伴う炎症性変化そして matrix metalloprotease などの蛋白分解酵素の誘導が，血 栓化動脈瘤の成長さらには破裂と密接に結びついていると 考えられる6)10)11)13)15-18)20)21)23．

一般に椎骨動脈の解離性病変は，出血発症でない限りお おむねその予後はよいとされている。これは椎骨動脈が左 右 2 本あるため一側に解離性病変が生じると, 一側の椎骨 動脈に狭窄を伴うため反対側椎骨動脈からの逆行性血流を 促し, 解離が進行しなくなるためと考えられる。しかし健 側椎骨動脈が細く血流が少ない場合には，病側の椎骨動脈 の血流は低下せず動脈瘤がさらに成長し, mass effectと なって脳幹部を圧迫, 解離腔の伸展による脳梗塞の発症, さらにはSAHの発症などをきたすことになる。

\section{椎骨動脈血栓性動脈瘤に対する外科的手術}

一般に巨大脳動脈瘤の予後は悪いことが知られている. Drakeは保存的に治療した 31 名の巨大脳動脈瘤患者の $70 \%$ が初発症状後の 2 年間に, 主にくも膜下出血によって 死亡したと報告している ${ }^{4)}$ 。

椎骨動脈に限局した血栓性動脈瘤は，多くの場合 PICA を巻き込んでいるので，OA-PICA anastomosisを行った のち, 病変部を trappingし aneurysmectomyを行うのが 最もよいと思われる1）. 血栓化椎骨動脈瘤は多くの場合, 動脈瘤は延髄，脳幹を持ち上げ，その裏側は強く癒着して いる. lateral suboccipital approachを行うと, 動脈瘤の 近位部 VA は容易に確保され，また容易に動脈瘤の上に IX，X，XI脳神経が挙上されているのがわかる。しかし遠 位部 VA は正中に存在することが多く，顔面神経の前後か ら遠位部 VA を確認する。しかし今回手術を行った 9 例中 2 例では aneurysmectomy 前に遠位部 VA を確認すること が困難なため，近位部 VA を閉塞後，出血を覚悟で血栓を 摘出したのちに遠位部 VA を確認し clipping できた。また 9 例中 1 例では遠位部 VA を反体側 VA と誤認した。術前 に脳血管撮影だけでなく，3D-CTで遠位部 VA を正確に 確認する必要がある。でないと trapping が不完全となり， aneurysmectomyのときに思わぬ出血に出くわし困惑す る.

一般に血栓性動脈瘤から直接分岐している穿通枝動脈は みられない場合が多いが，動脈瘤遠位部に穿通枝動脈が存 
在することがある。これは解離腔が動脈分岐部で止まるこ とが多いためである．9例中 2 例のみでそのような穿通枝 動脈を認めたが，血栓摘出後にクリップをできるだけ遠位 部におくことによって穿通枝動脈を温存できた。また動脈 瘤内血栓を摘出する場合, 特に下位脳神経は確実に温存し なければならない。 また多くの場合, 動脈瘤は延䯣, 脳幹 を持ち上げ, その裏側は強く癒着している場合が多いので, けっして乱暴に剝離してはならず piece by pieceに摘出す る必要がある. 血栓が柔らかい場合には各種の dissector で容易に摘出できる。しかし一部の血栓が石灰化している 場合は，一部を残して摘出を終了したほうがよい。われわ れの症例 9 例中 1 例で著明な石灰化のために血栓を残した が, 術後 2 年目にはほとんど吸収されていた。

われわれは OAを吻合する部位は PICA の lateral medullary segment を選択するが，ここに吻合すれば血流は順 行性にPICA 末梢へと流れていくので, 細い穿通枝動脈へ の還流不全も防ぐことができ，また開頭範囲も通常の lateral suboccipital approach を下方に広げるのみで問題はな かった．ただし約 $6 \mathrm{~cm}$ 深い術野での血管吻合となるので, 血管吻合の熟練とバイオネット型の血管結紮用摂子，持針 器が必要となる.

椎骨動脈に限局した血栓性動脈瘤は，成長し巨大化して 局在症状を呈する前に積極的に手術すべきと考えられた。 ただし解離性椎骨動脈瘤の発生は，両側性に生じることが まれでなくあるので，両側椎骨動脈の閉塞も考慮に入れて Allcock testによる後交通動脈の有無を術前に検討してお く必要である.

\section{血栓化脳底動脈瘤の手術}

Mizutani ${ }^{15)}$ は 13 症例の dolichoectasia of the basilar artery の最低 2 年以上の長期経過観察で 5 例に解離性動脈 瘤の合併が認められ予後不良の転帰をとったこと， Nishizaki ら ${ }^{19)}$ は 23 例 の dolichoectasia of the basilar arteryの分析で 2 例に血栓化した大きい囊状動脈瘤が椎骨 脳底動脈移行部に合併していたと報告している。これらの 報告は, dolichoectasia of the basilar artery が動脈瘤の発 生母地となる可能性を示唆しているが, その発生頻度とな ると明確ではない.われわれの症例でも5例中 3 例で dolichoectasia of the basilar arteryに巨大化血栓化動脈瘤 が合併していた。

椎骨動脈と異なり, 脳底動脈に血栓性, 増大性, 解離性 動脈瘤病変が生じた場合, その治療はきわめて困難であ る 1)4)5(14-16)20)21)25-27). もち万ん可能であれば, 脳幹部 を圧迫している血栓化動脈瘤自体の摘出が最も理想的な治 療であるが，これには多くの問題が残されている．脳底動 脈に発症し脳幹部を圧迫している脳底動脈瘤は, 動脈瘤の
摘出が最も理想的な治療方法である。しかし脳底動脈には 重要な穿通枝が多数存在しており, 動脈瘤と一緒に脳底動 脈そのものを取り除く場合，これらの穿通枝動脈の犠牲に よる脳幹梗塞は逃れない. 脳底動脈先端の後大脳動脈，上 小脳動脈には血行再建術が可能であるが，脳底動脈から直 接分岐する小さな穿通枝動脈には血行再建術は不可能であ る。そして穿通枝動脈領域の虚血耐性は, balloon occlusion testで前もって調べることはできない5)。また脳底動 脈を trapする場合，短時間でも穿通枝動脈閉塞による脳 幹梗塞を生じる可能性がある。 そのため脳底動脈からの穿 通枝動脈を傷つけず，血栓化した部分のみを摘出するか， 脳底動脈とその穿通枝動脈の血流を維持しながら動脈瘤の 成長を止めるために血流の方向を変えることが外科治療の 目標となる. Anson $ら^{1)}$ は, 脳底動脈本幹部の巨大紡錘上 動脈瘤に対して, 血栓摘出および脳底動脈の再建を行うた めに低体温，循環停止による手術操作が有効であったと報 告している.しかし血栓化病変は多くの場合の脳底動脈に 全周性に生じていることが多く，その病変のみを摘出する のは困難である.

次に考えられる治療方法は親動脈の閉塞であり, 脳底動 脈還流域の虚血を予防するために high flow bypassが行わ れている. bypass graftとして radial arteryが用いられて いるのは, radial arteryがvein graftに比較し, 後大脳動 脈と同じ直径であり縫いやすいこと，また吻合後長期間の 開存率が高いためと考えられる ${ }^{7) 9) 12)}$. Sundt Jr. ${ }^{25)}$ は, 4 例の脳底動脈紡錘状動脈瘤に対して脳底動脈結紫および vein graft を用いたhigh flow bypassを行っているが，全 例失っている. Drake ら ${ }^{4) 5}$ は，42 例の脳底動脈紡錘状動 脈瘤にたいして 32 例で親動脈結紮，6例で血栓摘出およ び trapping, 21例で wrapping, 1例で clipping そして残 り1例で exploration onlyを行っているが，11例の死亡 (26\%), severely disabled 1 例と報告している。また前述 したAnson $ら^{1)}$ の成績は，11例の脳底動脈本幹部の巨大 紡錘状動脈瘤にたいして，死亡例 3 例， severely disabled 2 例と報告している.

われわれは脳底動脈の血流を維持しながら動脈瘤の成長 を止めるために血流の方向を変え, かつ血流速度を遅くし て動脈瘤全体を血栓化させながら側副血行路ができること を期待してVA-RA-PCA bypass後のBA 閉塞を選択した. 全例で high flow bypassは良好に流れ術直後にはへパリン を使用していたにもかかわらず，脳虚血を合併した，そし て 5 例中 3 例で，脳虚血症状は不可逆で重篤な後遺症を生 じた。また 1 例ではへパリンの中止後急激に脳幹梗塞が進 行した。今回の手術結果は, 単純に親動脈の閉塞した Drake らの結果より悪いのは明らかで, Sundt ${ }^{25)}$ の結果 に近い. 血栓化脳底動脈瘤では脳底動脈の内皮細胞が剝 
離しているために，容易に新たな血栓ができる．おそらく high flow bypassでは血流が盲端となった脳底動脈に逆流 し，むしろ血栓を舞い上げて穿通枝動脈に流れ込み脳幹部 梗塞を生じたのではないかと推測される。

また術後血栓化動脈瘤は血管撮影で造影されなくなって も縮小せず，むしろ 1 例では時間とともに増大した. high flow bypassを介しての十分な血流が逆行性に脳底動脈に あるので，動脈瓷内血栓の成長が壁内出血により続いたの ではないかと推測された。血栓化した動脈瘤が, 破裂し出 血した報告は数多くあり，動脈㢚が血栓化しただけでは安 全とはいえない8)13)27).

いずれにしろ Hunterian ligation with high flow bypass で治療した場合, 術後急性期虚血の発生, そして成長の止 まらない動脈瘤に対しては 2 次的な外科処置が考慮されな ければならない，血栓化巨大脳底動脈瘤の外科治療が今後 どのように洗練されていくかはわからないが，今後 covered stentなどの血管内外科治療も考慮されるべきと思わ れる.

\section{文献}

1) Anson JA, Lawton MT, Spetzler RF: Characteristics and surgical treatment of dolichoectatic and fusiform aneurysms. J Neurosurg 84: 185-193, 1996

2) Aoki N, Sakai T, Oikawa A, et al: Giant unruptured aneurysm of the vertebral artery presenting with rapidly progressing bulbar compression--case report. Neurol Med Chir (Tokyo) 37: 907-910, 1997

3) Chen JW, Zabramski JM: Giant fusiform and serpentine aneurysms, in Awad AI, Barrow DL (eds): Giant Intracranial Aneurysms, Park Ridge III American Association of Neurological Surgeons, 1995, pp233-252

4) Drake CG: Giant intracranial aneurysms: experience with surgical treatment in 174 patients. Clin Neurosurg 26: 12-95, 1979

5) Drake CG, Peerless SJ: Giant fusiform intracranial aneurysms: review of 120 patients treated surgically from 1965 to 1992. J Neurosurg 87: 141-162, 1997

6) Endo S, Nishijima M, Nomura H: A pathological study of intracranial posterior circulation dissecting aneurysms with subarachnoid hemorrhage: report of three autopsied cases and review of the literature. Neurosurgery 33: 732-738, 1993

7) Houkin K, Kamiyama H, Kuroda S, et al: Long-term patency of radial artery graft bypass for reconstruction of the internal carotid artery. Technical note. J Neurosurg 90: 786-790, 1999

8) Isla A, Alvarez F, Roda JM, et al: Serpentine aneurysm: regrowth after a superficial temporal artery-middle cerebral artery bypass and internal carotid artery ligation: case report. Neurosurgery 34: 1072-1074, 1994

9) Kamiyama H: Bypass with radial artery graft. No Shinkei Geka 22: 911-924, 1994

10) Kansaku K, Hirai S, Kobayashi E, et al: Serial magnetic resonance imaging of acute spontaneous thrombosis of a giant intracranial aneurysms--case report. Neurol Med Chir (Tokyo) 38: 562-565, 1998

11) Katayama $Y$, Tsubokawa $T$, Miyazaki S, et al: Growth of totally thrombosed giant aneurysm within the posterior fossa: Diagnosis and therapeutic consideration. Neuroradiology 33: 168-170, 1991

12) Kobayashi M, Kamiyama H: Reconstruction of the basilar arterial system: methods of high flow bypass in posterior cranial fossa. Surg Cereb Stroke 27: 270-276, 1999

13) Koyama S, Kotani A, Sasaki J: Giant basilar artery aneurysm with intramural hemorrhage and then disastrous hemorrhage: case report. Neurosurgery 39: 174-178, 1996

14) Locksley HB: Report on the Cooperative Study of Intracranial Aneurysms and Subarachnoid Hemorrhages. Section V, Part II. Natural history of subarachnoid hemorrhage, intracranial aneurysms and arteriovenous malformations. Based on 6368 cases in cooperative study. $J$ Neurosurg 25: 321-368, 1966

15) Mizutani T: A fatal, chronically growing basilar artery: a new type of dissecting aneurysm. J Neurosurg 84: 962-971, 1996

16) Morley TP, Barr HWK: Giant intracranial aneurysms: diagnosis, course, and management. Clin Neurosurg 16: 73-94, 1969

17) Nagahiro S, Takada A, Goto S, et al: Thrombosed growing giant aneurysms of the vertebral artery: growth mechanism and management. J Neurosurg 82: 796-801, 1995

18) Nakatomi H, Segawa H, Kurata A, et al: Clinico-pathological study of intracranial fusiform and dolichoectatic aneurysms: insight on the mechanism of growth. Stroke 31: 896-900, 2000

19) Nishizaki T, Tamaki N, Takeda N, et al: Dolichoectatic basilar artery: a review of 23 cases. Stroke 17: 1277-1281, 1986

20) Ogiichi T, Endo S, Onizuka K, et al: Non-aneurysmal subarachnoid hemorrhage associated with basilar artery dissection--autopsy case report. Neurol Med Chir (Tokyo) 37: 612-615, 1997

21) Reznik M, Mouchette R, Delcour C: Giant fusiform aneurysm of the basilar artery. Clinicopathological report of 3 cases. Acta Neurol Belg 84: 141-150, 1984

22) Roach MR: An experimental study of the production and time course of post-stenotic dilatation in the femoral and carotid arteries of adult dogs. Circ Res 13: 537-551,

23) Shokunbi MT, Vinters HV, Kaufmann JC: Fusiform intracranial aneurysms. Clinicopathologic features. Surg Neurol 29: 263-270, 1988

24) Stehbens WE: Experimental arterial loops and arterial atrophy. Exp Mol Pathol 44: 177-189, 1986

25) Sundt TM Jr, Piepgras DG, Marsh WR, et al: Saphenous vein bypass grafts for giant aneurysms and intracranial occlusive disease. J Neurosurg 65: 439-450, 1986

26）氏家 弘, 比嘉 隆, 堀 智勝, ほか：How I Do It 21)Dolichoectatic giant aneurysm of the basilar artery. 脳神 経外科 31: 76-88, 2003

27）氏家弘, 比嘉 隆, 堀 智勝: Dolichoectatic basilar aneurysmの自然予後および現在の治療状況一アンケート調 査の分析一. 脳卒中の外科 32: 338-345, 2004 